\title{
The "Cairé" and "The Ghost of Komat" Textual Landscapes and Cultural Heritage in Argentinean and Slovenian Folktales
}

\author{
Maria Palleiro
}

Prispevek s stališča fiktivne konstrukcije mitskih krajin primerjalno obravnava argentinske in slovenske pravljice, ki imajo tematske značilnosti z ATU 326 ("Mladina, ki se je želela naučiti, kaj je strah"). Primerjava je usmerjena k prepoznavanju podobnih pripovednih vzorcev, ki so povezani ne le s tematskimi vrstami pravljic, temveč tudi s strukturnimi in slogovnimi značilnostmi in drugimi spremenljivimi podrobnostmi. Tematske, strukturne in slogovne značilnosti, ki so skupne različnim variantam, ustrezajo pripovedni matrici, ki deluje kot pretveza za poustvarjanje $\mathrm{v}$ različnih pripovednih kontekstih. Spreminjajoče se podrobnosti dajejo nov pomen univerzalnim vzorcem, povezanim s kulturno dediščino različnih lokalnih kontekstov, kot sta argentinski in slovenski.

KLJUČNE BESEDE: povedke, Argentina, Slovenija, bajčne pripovedi, mitske pokrajine, nesnovna kulturna dediščina
The present article proposes a comparative approach to Argentinean and Slovenian tales that share thematic features with ATU 326 ("The youth who wanted to learn what fear is") from the standpoint of the fictional construction of verbal landscapes. The comparison is oriented to identifying similar narrative patterns dealing not only with thematic tale types but also with structural and stylistic features, along with changing details. The thematic, structural, and stylistic features common to different versions conform to a narrative matrix, which acts as a pretext to be recreated in diverse narrative contexts. The changing details give new meanings to universal pattern connected with the cultural heritage of different local contexts, such as the Argentinean and the Slovenian ones.

KEYWORDS: folktales, Argentina, Slovenia, belief narratives, textual landscapes, intangible cultural heritage

\section{INTRODUCTION}

Folk narratives provide a verbal construction of cultural landscapes. Such construction of "textual landscapes" (Venturoli 2004) can be seen in Argentinean and Slovenian folk narratives, such as those analysed through a comparative approach. These narratives share thematic features with ATU 326, "The youth who wanted to learn what fear is". The Argentinean ones are also connected with ATU 330A, "The smith and the Devil".

As will be explained, the comparison between Slovenian and Argentinean versions reveals not only thematic but also structural and rhetorical similarities along with changing 
details. Such details, considered by Mukařovský (1977) to be basic semantic units in folk art, are linked with contextual transformations of (pre-)textual common patterns, which express the differential identity of local cultures.

\section{THE CAIRE: A TEXTUAL CONSTRUCTION OF ARGENTINEAN VERNACULAR LANDSCAPE}

The Argentinean version, whose narrator is Cesar Soria, aged sixteen, is located in "a small ranch" of "La Maravilla" in the northwestern province of La Rioja. The Argentinean northwest is a geographic and cultural region near the Andes mountains, where indigenous vernacular cultures such as Diaguitas and Incas have settled their domains. The Incas, who spoke the Quichua language, established the Tawantinsuyu Inca domain, which left cultural traces such as a track system called Quapaq Nam (literally "Great Way"), also known as "the Inca track". The province of La Rioja is located in this zone, whose geographical and cultural landscape corresponds to the Argentinean part of the Qhapaq Nam, declared in 2014 by UNESCO as World Cultural Heritage, under the category "Cultural Itineraries". The landscapes of the Inca track - involving six South American countries: Ecuador, Colombia, Perú, Bolivia, Argentina and Chile - comprise ranches where it is said that Inca treasures, such as the one mentioned in the Argentinean version, have been hidden. During the early $16^{\text {th }}$ century, the Spaniards conquered South America, and indigenous people suffered a demographic decline. From this period until the $18^{\text {th }}$ century, there was a consolidation of Spanish power, and the beginning of the $19^{\text {th }}$ century found the Créole society - a blend of indigenous and Spanish cultures - mature enough to face the War of Independence, which ended in 1816. Since that independent period, other waves of immigration from the European world took place. Spaniards, Italians, along with Jewish and even Slovenian immigrants, settled in northwestern Argentinean provinces, such as Mendoza, and also in the mesopothamian and southern regions (Palleiro \& Peltzer, in print).

As a consequence of this historical development, indigenous cultures have a strong influence in the Argentinean northwest. The Quichua language is still spoken by Créole populations whose indigenous ancestors were indoctrinated by Catholic missionaries who used vernacular languages in catechisms. Thus, this region shows the blend of indigenous vernacular cultures with the heritage of Spanish conquerors and European immigrants in a heterogeneous landscape reflected in the narrative versions.

\section{LEGENDS AS INTANGIBLE CULTURAL HERITAGE ISSUES}

Both the Slovenian and Argentinean versions have been presented as "legends" and "real cases." As characterised by Tangherlini (1990: 385), a legend is a traditional historically grounded narrative discourse, with short episodes, performed in a conversational format, which reflects symbolic representations of collective experiences and commonly held 
values such as the ones expressed in the Argentinean and Slovenian versions. Connected to the historicised nature of legend is the relationship with folk beliefs (Dégh, Vázsonyi 1976), reflected in the narrative texts, whose contextualisation processes involve the construction of textual landscapes (Venturoli 2004).

Since 2003, UNESCO has underlined the relevance of safeguarding patrimonial intangible heritage (PCI), which involves social practices that intervene in the processes of production of material and symbolic manifestations. As a folklore genre that reactivates the collective memory, the legend is part of this intangible heritage, referred to as knowledge transmitted from generation to generation by vernacular narrators like the Argentinean and Slovenian ones who recreate symbolic expressions of local cultures in legendary formats.

\section{TALE TYPES, NARRATIVE MATRICES, AND RHETORIC OF BELIEVING IN LEGENDARY DISCOURSE}

The distinctive feature of the legend as a folklore genre is the double connection with the semantic domain of belief and with fictional discourse, anchored both in reality and in the out of the ordinary world (Cook 2008: 13-16). Such a liminar domain is linked with the invention of traditions, actualising the past in the present (Fine 1989) and transmitting collective cultural values.

The legends analysed here share the same narrative matrix, understood as a set of thematic, structural and stylistic features, which can also be found in folktales (Palleiro 2004, 2018), whose contextual transformations and changing details (Mukarovsky 1977) give new meanings to a universal pattern, expressing the differential identity of each social group (Bauman 1972). When studying traditional storytelling, Dégh (1995: 259) affirms that, from the narrator's viewpoint, belief and credibility play an important part, as well as respect for tradition. Belief narratives are part both of individual and social memory, in an intertwining of universal patterns and local cultures, as can be seen in the texts here considered, whose discursive construction seeks credibility through argumentative resources. From a semiotic perspective, belief is a modal expression of truth, in which the true value of discourse depends on a social consensus (Greimas \& Courtès 1982; Palleiro 2008). As Valk (2019) wisely affirms, a legend may appear to be a historical narrative because of reference to verifiable geographic features and culturally credible characters. Simply because it is often performed as true, the narrative content itself is not always an actual reflection of a historical event (Tangherlini 1990). In this sense, Oring (2012) underscores that these narratives draw not necessarily on truth but on a rhetoric of truth and on a rhetoric of believing (Palleiro 2008). The context and the social performance are relevant aspects of legendary discourse (Abrahams 1976), and contextual variations transform narrative matrices into expressions of vernacular identities, as can be seen in Argentinean and Slovenian versions.

The narrative patterns textualised in matrices are also anchored in festivals and rituals, which give meaning to the daily life of towns, cities, and other local spaces, becoming 
expressions of vernacular cultures. This is how, for instance, the distinctive features of the northwestern Argentinean culture are recreated in legends, rites, and festivals, such as the Salamanca one, bound both to indigenous Quichua-Diaguita and Spanish heritage. According to the vernacular narrator Marino Cordoba, the Salamanca is a ritual ceremony whose climax is the moment in which a "deal with the Devil" is achieved (Cordoba 2016: 54-58). The deal with the devil is also an ATU tale type, classified under number 330, "The smith and the Devil", and it can also be considered as a narrative matrix whose sequential structure is organised into different episodes, such as the meeting of a man or a woman with the Devil personified, the accomplishment of the deal, the benefits obtained or the punishments for having refused it, with variants like the ones in which the man or the woman outwits the devil by trickery. ${ }^{1}$ The rhetoric structure is based both on the personification of evil forces and the antithesis between devilish powers and human cunningness. This universal pattern, common to different contexts, can also be found, for instance, in local Estonian folklore, as a folktale and a religious rite, associated with vernacular beliefs (Valk 2001).

To summarise, legendary discourse, historically grounded, deals with the rhetoric of believing in a tension between universal patterns and contextual variations. Thus, the same narrative matrices, such as haunted houses and the deal with the devil, express vernacular identities in different contexts, such as the Argentinean and Slovenian ones.

\section{HAUNTED HOUSES IN ARGENTINEAN FOLK NARRATIVE}

The Argentinean version, whose title, given by the young narrator César Soria, is "The 'Cairé'. It is about a gaucho (horseman) fighting with the Devil in La Maravilla" and was collected in fieldwork in the northwestern region in 1986, along with other narratives dealing with haunted houses. In previous works, this text has been studied from the standpoint of vernacular religion (Palleiro 2012: 211-229) and classification issues (Palleiro 2020). Here, the analytical perspective is that of the rhetorical construction of cultural landscapes. As stated, this narrative (classified by the narrator both as a "legend" and as a "case") is close to the "memorate" since it refers to an event told to the narrator as a personal experience by a member of his family and shares thematic features with ATU tale type 326: "The youth who wanted to learn what fear is". ${ }^{2}$ The protagonist is a gaucho who enters a haunted ranch of La Maravilla, where a treasure was hidden. Once inside, he decides to remain there overnight and, at midnight, different pieces of a corpse begin falling from the ceiling, one by one, until all of them are shaped into a devilish body. As soon as this happened, the "gaucho" begins fighting with the Devil personified until he obtains wins. This thematic plot has the structure of an oral version of personal

\footnotetext{
1 Such narrative matrix acts as well as a pre-text for fictional tales such as the one by José Corso (Palleiro 1990: 47-51) "Pedro Ordimán and the Devil" that follows this sequential structure with an alternative itinerary, according to which the trickster Pedro Ordimán manages to outwit the devil after having made a deal with him. 2 From the ATU tale type, this itinerary develops into itinerary dealing with motif E 281 "A youth spends the night in a haunted castle" in this variant.
} 
experience (Labov, Waletzky 1967), with an initial abstract in which the narrator orients the audience to the plot's theme, space and time (at La Maravilla, when his grandfather was a little child), followed by a problem, caused by the ghostly apparition of a strange creature falling from the ceiling, which provokes a fight. This main sequence is followed by an evaluative clause that gives the narrative its significance by pointing out the relationship of this creature with the supernatural, expressed in the phrase "That it was the Devil, who fell down from the ceiling" (Palleiro 1990a: 51). The resolution, coinciding with the victory of the courageous man over the devilish creature, is followed by a coda, which is the most important clause of this version since it mentions the deal with the Devil, whose thematic elements correspond to ATU type 330, "The smith and the Devil". The basis of the rhetoric structure is the synecdochic fragmentation of the devilish body and the antithesis between good and evil, symbolised in the metaphor of the combat, in which the gaucho, a vernacular character, obtains the victory. The devilish creature is personified as a human being, and such personification is connected with collective beliefs in anthropomorphic representations of the supernatural. The narrator also uses argumentative resources such as the allusion to eyewitnesses to convince the audience about the believability of the plot. Such thematic, structural, and rhetoric features constitute the narrative matrix, which serves as a pretext for different textualisations, including the Slovenian and Argentinean ones.

In the Argentinean version, the rhetoric construction of the landscape is connected with the setting of the narrative plot. Thus, the ranch of La Maravilla is presented as a haunting landscape, where "no one could enter, since it had been occupied by a devilish being, whose ghostly apparition frightened any visitor" (Palleiro 1990a: 53). The universe of vernacular beliefs connects the pre-textual matrix with a local anecdote dealing with haunted houses inhabited by the Aguirres, who made a deal with the Devil and hid a treasure in a "ranch":

My grandfather Pablo told me that, when he was a little boy, a gaucho, an Argentinean horseman, has gone to a little ranch. And that at night, suddenly, he has heard a voice saying: - Should I fall or should I not fall? - So! Come and fall, once and for all! - he said [...] That it is said that the Aguirres had made a deal with the Devil. That a treasure had been hidden for years, in that small ranch. And that a sort of curse was made. And, from that moment on, people who dare to enter that ranch are scared by such devilish beings (Palleiro 1990: 53-54).

Since the times of the Spanish conquerors, legends regarding hidden treasures of aboriginal people have been circulating in rural areas like this one of La Maravilla, in La Rioja province. Thus, the text shows the blending process of the folk matrix and the legend with a local case, dealing with the members of a family who existed. The narrator includes allusions to ghostly apparitions as metaphoric representations of devilish forces, which are part of the cultural landscape of La Rioja. In a synecdochic identification, such ghostly apparitions that scare people at night are called "Scares", presented in Soria's narrative 
not only as ghosts but also as concrete beings that protect the ranch against invaders, in a personification process (“And that is why there are 'Scares' at the Aguirre's, there, in that small ranch of La Maravilla") (Palleiro 1990a: 54). These hidden treasures protected by ghostly beings can be interpreted not only as material possessions but also as symbolic representations of local cultures. It is also worth noticing that the one who managed to outwit the Devil is a vernacular gaucho and not a foreign invader. The allusions to real people serve as argumentative strategies oriented to convince the audience about the tale's believability, as are the modalising clauses, such as "This is true" (Palleiro 1990a: 54). These stylistic issues are linked with the aforesaid rhetoric of truth, referred not only to the empirical validation of an event but also to a set of cultural values. The version is thus presented as a belief narrative, whose veracity is supported by a communitarian consensus. In this way, the community's voice, introduced in the clause "it is said in La Maravilla" operates as a source of social endorsement, reinforced by deictic clauses related to the local context, confirming the narrative's collective dimension.

\section{CONTACTS WITH THE SUPERNATURAL IN THE VOICE OF AN ARGENTINEAN VERNACULAR NARRATOR}

The metaphoric condensation of human beings and supernatural forces can also be found in the Salamanca ritual in which, as stated, a deal with the Devil takes place. As mentioned above, when the Spanish conquerors arrived in South America imposing a Catholic worldview with a series of conceptions regarding God and the Devil, alien to vernacular cultures, a transculturation process of European heritage took place. This ritual is an example of such transculturation, reflecting social beliefs resulting from a blend of different elements, no longer Spanish nor indigenous but créole (Palleiro, Peltzer, in print).

The narrative development of the Salamanca has been referred by the craftsman Marino Cordoba in a personal interview held in his atelier in 1987. The artist created a series of pottery pieces representing different episodes of this rite, nowadays exhibited in the Folklore Museum of La Rioja and in the Museum of the Devil of Kaunas, Lithuania. As a rite, the Salamanca consists of a sequential repetition of actions, with a performative intention of achieving effects on the context (Rappaport 1992; Palleiro 2008), whose climax is the sequence in which, as aforesaid, "a man or a woman sell their soul to the Devil" (Cordoba 2016: 54-58). Cordoba referred to the different steps while showing the statuettes, in sequential order, and his narrative discourse reflected both symbolic representations of folk beliefs in a psychological level, as well as collective experiences that affirm commonly held values associated with a rhetoric of truth, which are distinctive features of legendary discourse (Tangherlini 1990).

The narrative's starting point was the statuette representing the devil under the zoomorphic appearance of a goat. The Salamanca is the encounter with the Devil in the shape of a black goat, or a pig, a dog, any animal. The craftsman shows a statue of the Devil represented in the form of a goat (Cordoba 2016: 54). The rhetoric axis of Cordoba's discourse has been the metaphoric condensation of animals and human features in the figure of different 
characters, whose counterpart is the synecdochic processes of fragmentation reinforced by descriptive strategies, similar to the ones of Soria's version. The initial sequence of the "Encounter with the Devil" coincides with an opening clause explaining the global significance of the Salamanca through the allusion to zoomorphic metamorphosis, which constitutes not only the metaphoric expression of the whole rite but also the image of a worldview that underlines the relationship of reality with the supernatural. As explained below, such a relationship can also be found in Slovenian folklore, in which wandering souls have the power to take both the form of an animal and of a human being (Kropej et al.2010: 88). It is noteworthy that the nomination of the Devil as Zupay (linked to the Quichua culture) along with the allusion to the "Master of the Salamanca" (Cordoba 2016: 54-55), associated with the famous Spanish University and, thus, with a learning situation. In this way, the ceremony is presented as an initiation rite led by a supernatural devilish teacher. This plural reference to the Devil reflects the cultural syncretism of the whole community, which is part of the northwestern Argentinean landscape.

As referred in Cordoba's narrative, before achieving the deal with the Devil, the participants of the ceremony or salamanqueros must follow different ritual steps, such as to trample and spit the Holy Cross, to bear snakes crawling out of the body, to walk over hot embers and to enter a pool of ice water. Those who do not fulfil these tasks are seriously punished; these ritual punishments are narrated by Cordoba in a final macro-sequence, which develops the topic of zoomorphic transformations, with one of the toads whose vernacular name is the guacacho, presented by Cordoba as a punished singer:

And that there are also the 'punished' ones: the toad, the guacacho [...] The toad has been a singer who has gone to the Salamanca [...] He hid inside a guitar, and he did not follow all the ritual steps, so then, the Devil punished him, and he turned him into a toad, full of stains (Cordoba 2016: 57).

Such ritual practices have been documented in communities of the Argentinean northwest by the psychiatrist Fernando Pagés Larraya in research regarding collective hallucinations, which has revealed the impact of social beliefs in collective mental health (Palleiro 2016: 228). Furthermore, these ritual punishments can be considered "impossible tasks", which acquire the performative meaning of an act of blasphemy against God, symbolised in the initial task of rejection of the Holy Cross, as a sign of the Hispanic Catholic culture. The thematic motif of the "impossible tasks" appears in ATU tale type 330, "The smith and the Devil".

Regarding the connection between rite and the tale types, it is worth considering a metanarrative clause in which Cordoba makes a distinction between the rite and the fictional discourse, affirming the ontological dimension of beliefs: "All that happens in the Salamanca is true, it is a rite which must be accomplished. But from this rite, people find inspiration to tell histories and [fictional] tales." (Cordoba 2016: 58). Thus, the narrator underscores the difference between the semantic domain of fictional discourse in which he places the folktales, and the semantic domain of the rite, associated with "true" actions. In this way, he considers both "histories" and "tales" (comprising "legends") 
as fictional discourses, associated with the "rhetoric of believing" (Palleiro 2008), in an implicit allusion to the poetic recreation of history (White 1973).

To convince the audience about the veracity of his discourse, Cordoba intersperses a local "case" regarding a rascal who once went to a Salamanca by chance when he was returning home at night, and he heard music near a canyon.

Then, he was invited to enter a cave, where he met a musician who was an old, toad-faced, ugly creature. And he danced and ate some tasty food [...] And when he was about to return home, they gave him a parcel, to take it to his mother. The day after, when he woke up [he opened the package and] he realised that the tasty stuff had been changed into waste, somewhat like donkey dung. And he told this to his friends, and his friends asked him: 'Do you know where have you been? In a Salamanca!' (Cordoba in Palleiro 2016: 56-57).

The semantic axis of this local "case", or strange event happened to a community member. It includes the antithesis between a beautiful appearance and an evil essence, represented by the contrast: tasty food turned into donkey dung. This memorate, interspersed in the sequential development of the rite, is structured, in the same way as Soria's version, as a narrative of personal experience (Labov, Waletzky 1967), with an orientation clause that locates the action in a real space and time and a thematic point, which is the metamorphosis of the delicacies into rubbish, within the dynamic of transformations of the Salamanca. This narrative of personal experience serves the function of an argumentative proof of the believability of discourse endorsed by the community's voice. As it will be explained below, the Slovenian version also refers to a local anecdote (or memorate) connected with the supernatural, dealing with a ghostly apparition in the town of Komat.

\section{THE MUSEUM AS A FRAME FOR CULTURAL LANDSCAPES}

A symbolic space of legitimation of Cordoba's artistic work dealing with the Salamanca as local cultural heritage is the Folklore Museum of La Rioja, placed almost at the end of the Inca track, in the confluence of the Quichua and diaguita cultures. Such location influenced the genesis of the craftsman's work, conceived as a set of pieces to be exhibited in a museum setting. The disposition of the statuettes in the Folklore Museum has been documented in two different periods, in 1994 and 2001. In 1994, such statuettes were exhibited in a room, in non-sequential order, with a few explanatory paratexts, sharing the space with indigenous objects such as arrowheads and vessels, catalogued as samples of vernacular material culture and tangible heritage. The classification of "material culture", used by the Folklore Museum as a qualifying parameter, implied the reference to a collectionist paradigm of folklore, related to the accumulation of objects from the past for the rescue of a cultural memory, according to the sense of the term "folklore" given by Thoms (1846). In the second period, the statuettes were displayed in sequential order, 
in concentric circles over wooden trunks, around a central statuette, which corresponds to the deal with the Devil, in a specific room devoted to the Salamanca, in which they are still placed. Such location underlines the authorship of Marino Cordoba as an individual artist who managed to recreate the cultural heritage of his community. Moreover, the museum provides visitors explanatory sheets suggesting a narrative tour, which proposes an order of the statuettes that emphasises the ritual sequences of initiation, impossible tasks and punishment. Such paratextual explanations highlight the connection of these vernacular social beliefs with the indigenous cultures of the Qhapaq Nam, where their most important traces can be found.

As stated, the ritual transformations of the Salamanca reflect a dynamic worldview that mixes elements of vernacular cultures juxtaposed with Catholic mythology. Such a mixture is also the main principle of folklore composition, characterised by Mukařovský (1977) as a mosaic-like structure, formed from the juxtaposition of heterogeneous semantic units. Thus, the Folklore Museum of La Rioja acts as a symbolic space whose function is both to preserve local collective cultural heritage and to encourage individual artistic expressions such as Cordoba's one. Furthermore, the Museum of the Devil of Kaunas in Lituania provides framing issues (Goffman 1992, Lotman 1978) to the aesthetic production of Cordoba, proposing a reception of his artistic work as part of the Argentinean cultural landscape.

\section{THE SALAMANCA FESTIVAL}

Another artistic expression of this rite is the Salamanca festival. This event, lasting five nights, spreads music and local culture in Santiago del Estero Argentinean province, located in the area of the Inca track. The festival also serves to help needy communities, since part of the earnings is distributed among assistance centres and local schools (Palleiro and Peltzer, in print). Like in La Rioja, also in Santiago del Estero, the Salamanca is part of the vernacular living culture, based on the legend, which acts as a narrative pretext of the festival. In Santiago del Estero, it is said that the Salamanca is a difficult-to-access cave located in the deepest part of a mountain, and whoever enters there manages to earn much money without any effort, as well as to display extraordinary abilities in playing musical instruments, seducing women, and enjoying all pleasures. In order to achieve this goal, the salamanquero - that is to say, the participant of the Salamanca rite - signs a contract with Zupay, the vernacular Devil, who grants his wishes in exchange for his life and soul.

The festival was held for the first time in 1992 at the Club Sarmiento of La Banda, a few kilometres from the capital of Santiago del Estero and, since the very beginning, it has been a communitarian event held with the support of social centres that contributed in the fundraising and organisation. The festival offers the local public food, such as catfish and other specialities. Year after year, the event grows among both locals and tourists. Concerts of prominent national and international musicians take place in the festival, including a musical contest, the Taki Mosoj ("New Year songs", in Quechua language) for emerging artists. Regarding the stage effects, in each edition of the festival, held regularly during 
February, every night a large poster with the letters $L A S A L A M A N C A$ is prepared with red icons simulating the salamanquero fire (Palleiro \& Peltzer, in print). In this festival, folklore and fakelore (Dorson 1976, Bendix 1997) are mixed, in a process of invention of traditions connected with the tourism industry. This event combines theatrical and ritual performances, displaying relevant aspects of social life and collective identities ${ }^{3}$ connected with the cultural heritage of northwestern Argentinean culture.

\section{“THE GHOST OF KOMAT”: GHOSTLY CREATURES IN THE SLOVENIAN CONTEXT}

The narrative matrix of "A ghostly apparition" can also be identified in the Slovenian tale "The ghost of Komat" (Kropej et al., 2015: 100) which is associated with local beliefs regarding "wandering souls". In this tale, the soul of a cheating neighbour has to return from the other world to the land named Komat as a ghost carrying a boundary stone on his shoulder each night because he shifted such a stone to get the land that belonged to his neighbour. In Slovenia, the appearances of so-called "punished souls" for such a sin were widespread in folk belief. Such ghosts or "cursed souls" were named meraš (the one measuring), džiler (engineer) or preklesa (cursed), and they had to carry their burden until someone saved them (Kropej 2012: 186-187). This was explained by the editors of this tale in an introductory note regarding Slovenian vernacular beliefs about such terrifying phantoms of the souls of deceased people who have to pay for their sins appear in the form of an animal (bird, dog, wolf, cat, mouse, dormouse, snake, toat, horse, bull, deer, bear) or in the form of a human being (Kropej, Šmitek, Dapit 2015: 88).

The comparison of the Argentinean version with the Slovenian one shows interesting similarities, along with contextual differences. In both of them, the action is grounded in a specific location: at "La Maravilla, La Rioja" in Argentina and in the field named Komat, between the villages Male Lašče and Poinvke, in the Slovenian one. The antagonist is a supernatural creature, presented as a ghost in the Slovenian version, and as a ghostly apparition, named "the Cairé" in the Argentinean one. The ghostly apparition is a personified being who asks a similar question employing a similar modal form, which is "Should I fall or not?" in the Argentinean version, and "Where should I put it?" in the Slovenian narrative. In both cases, such modalisation places the narratives in the arenas of belief. The versions dealing with the semantic domain of fear associated with the supernatural and the answer from the earthly world tends to restore a broken order expressed through a synecdochic counterpoint. The two narratives reflect a quest for sense, expressed in a final explanation: the Slovenian version refers to the fact that the protagonist attempted

\footnotetext{
3 It is worth remembering the characterization of "performance" given by Schechner (2004) who, following Turner, considers that this concept comprises both theatrical representations, rituals and everyday life events such as sports, dance and ceremonies.

4 The Spanish idiom "Cairé" means "I will fall".
} 
to guess what the ghostly voice meant, and the Argentinean one affirms that the voice belongs to a devilish being who has been protecting a hidden treasure. Both narratives connect the ghostly apparition with conflicts for the possession of the land. In the Slovenian tale, there is a conflict between the two neighbours quarrelling endlessly over a piece of land. One of them was moving the boundary markers. For this sin, he is punished and appears in the nights as a ghost carrying the boundary stone. In contrast, the Argentinean tale alludes to a "small ranch" where a hidden treasure is protected against invaders by supernatural forces. It is worth noting that this relationship between ghostly possessions and living conflicts dealing with ownership of land has also been documented by Valk (2006) in contemporary Estonian folk narratives.

Furthermore, the Slovenian version is presented by the narrator as a recollection from his childhood that resemantises the past from the present. Also, the Argentinean narrator presents his narrative as a remembering of his grandfather's childhood projected towards the present times, in which the consequences of a "deal with the devil" are still being experienced. Thus, the space becomes a cultural landscape, enriched by vernacular beliefs that turn both the Argentinean ranch and the field of Komat into haunting places. Moreover, the explanatory note of the Slovenian collection, which alludes to souls that take the form of an animal or a human, introduces a description of supernatural forces similar to the one mentioned by the Argentinean narrator Marino Cordoba who, as stated, affirms that, in the Salamanca ceremony, the Devil appears in the shape of different animals (Cordoba 2016: 54). In the Argentinean narrative, the haunting presence is associated with a deal with the Devil mentioned by the narrator Soria in the final coda, in which he alludes to a wandering soul with whom the vernacular "gaucho" held combat. In this way, both narratives reconstruct cultural landscapes connected with vernacular beliefs. Such local landscapes are in Argentina reframed in tourist festivals performed in places connected with touristic itineraries as the Qhapaq Nam - the Inca track - declared by the UNESCO as part of the World Cultural Heritage. Tourists are encouraged to follow this track visiting different places bound to vernacular traditions, highlighted in folk narratives. In this way, Qhapaq Nam becomes not only part of the tangible heritage but also of the intangible heritage contained in narrative messages. This connection between tangible and intangible heritage can also be recognised in Slovenian versions bound to existing local places, such as Komat. Thus, both the Slovenian and the Argentinean narratives draw textual landscapes that are part of the intangible cultural heritage, connected with local beliefs anchored in tangible places, such as the field named Komat, the ranch of the Aguirres, or even the Folklore Museum of La Rioja where the statuettes of La Salamanca are exhibited.

\section{FINAL CONSIDERATIONS}

Legends constitute the intangible cultural heritage of different local groups, such as Slovenian and Argentinean ones. Each new version gives contextual meanings to folk narrative matrices, creating cultural landscapes. Thus it happens with versions regarding 
the Cairé and the deal with the devil in northwestern Argentinean communities and with the ones regarding the ghost of Komat and other wandering souls in Slovenia.

In the Argentinean context, topics like the one of the deal with the Devil make room for visual representations, such as the la Salamanca pottery series by Marino Cordoba in the Folklore Museum of La Rioja, which is part of the local cultural heritage, and to performative events such as La Salamanca festival, showing a blend of European and indigenous cultures. These narratives show the relevance of social beliefs regarding the supernatural in everyday life, as reflected in anecdotes of real persons who participated in a Salamanca. Such narratives also include hidden treasures protected by ghostly beings, which can be considered metaphors of living conflicts. All these artistic expressions serve as touristic attractions to incentivise people to visit historic places that keep indexical traces of vernacular cultures.

Oral narratives express symbolic representations of the supernatural in ongoing societies such as Argentinean and Slovenian ones, referring to both intimate experiences regarding supernatural contacts with the dead and collective experiences regarding social life, such as the ownership of vital space threatened by foreign invasions. The contexts in which these aesthetic expressions are displayed show the connection between tangible and intangible heritage. Thus, oral versions dealing with la Salamanca act as pre-texts both of iconic statuettes exhibited in museums and of performative musical events, such as La Salamanca festival, which is not only a folklore expression but also a tourist attraction connected with fakelore and invention of traditions. Museums act as symbolic spaces that favour the patrimonialisation process of collective memories, creating institutional narratives, such as the one of the Salamanca provided to the visitors of the Folklore Museum of La Rioja. ${ }^{5}$

To summarise, narratives regarding haunted places show how the supernatural is represented in contexts such as the Slovenian field named Komat or the Andean world, whose geographic and cultural landscapes are part of the Qhapaq Nam, declared by UNESCO to be part of the World Cultural Heritage. The complexity of cultural landscapes makes necessary the arbitration of mechanisms of identification and protection for the development of tourist circuits. Through such forms of tourism, people can experience the fashions and lifestyles which these places involve (Palleiro \& Peltzer, in print). The concepts of tangible and intangible heritage are closely intertwined, as shown in the narratives analysed here, connected with the way of considering haunting spaces as a part of local identities, which are affirmed in the difference.

For further research, it is worth comparing other Argentinian and Slovenian supernatural beings such as the krivopeta and the Cai Pora, which are supernatural (female) beings with reversed feet that are said to be found beyond national boundaries such as the north-eastern South American zone of the one of the guaranytical area between Brazil, Paraguay and Argentina, and in the border area of Slavia veneta and the region of the Zgornja Soška dolina/Alto Isontino (Upper Soča river valley) between Slovenia and Italy.

\footnotetext{
5 "Institutional narratives" are the ones provided by cultural institutions such as the Folklore Museum that reconstructs traditional rites and other folk beliefs in a didactic register, oriented to explain it to the visitors.
} 
The revival of krivopetas as a local tradition has been recently studied by Barbara Ivančič Kutin $(2016$; 2017), not only in belief narratives but also in public storytelling events, theatre productions, reproductions in contemporary poetry, prose, music, the arts, education, tourism and other economic/business activities and services of the $21^{\text {st }}$ century.

Narratives regarding the Cai Pora and other mythical vernacular creatures have also been reframed in the present times in the Argentinian context in different oral, didactic and media discourses, as a result of a cultural policy of incentivising vernacular cultural heritage.

\section{REFERENCES}

Aarne, Antti; Thompson, Stith, 1961: The Types of the Folktale: A Classification and Bibliography. Second Revision (Folklore Fellows Communications 184). Helsinki: Academia Scientiarum Fennica.

Abrahams, Roger, 1976: The complex relations of simple forms. In: Ben-Amos, Dan (ed.), Folklore Genres. Austin: The University of Texas Press, 193-214.

ATU: Uther, Hans- Jörg, 2004. The Types of International Folktales: A Classification and Bibliography. Based on the System of Antti Aarne and Stith Thompson. Helsinki: Academia Scientiarum Fennica (Folklore Fellows Communications 284, 285, 286)

Bauman, Richard, 1972: Differential identity and the social base of Folklore. In: Paredes, Americo; Bauman, Richard (eds.), Toward New Perspectives in Folklore, Austin and London: The University of Texas Press, 31-41.

Bendix, Regina, 1997: From Fakelore to the Politics of Culture. The Changing Contours of American Folkloristics. In: Bendix, Regina (ed.), In Search of Authenticity. The Formation of Folklore Studies. Madison: University of Wisconsin Press, 188-218

Cook, Ryan, 2008: Prologue. In: Palleiro, Maria (ed.), Yo creo, vos ¡sabés?Retóricas del creer en los discursos sociales. Buenos Aires: Facultad de Filosofía y Letras de la Universidad de Buenos Aires, 261-263.

Cordoba, Marino, 2016: La Salamanca y otras creencias. In: Palleiro, Maria (ed.), El cuento folklórico riojano: una aproximación a la narrativa oral. Buenos Aires: La Bicicleta, 54-58.

Dégh, Linda; Vázsonyi, Andrew, 1976: Legend and belief. In: Ben-Amos, Dan (ed.), Folklore Genres. Austin: The University of Texas Press, 93-123.

Dégh, Linda, 1995. Narratives in Society: A Performer-centered Study of Narration. Helsinki: Suomalainen Tiedeakatemia / Academia Scientiarum Fennica.

Dorson, Richard, 1976: Folklore and Fakelore. Essays Toward a Discipline of Folk Studies. Harvard: Harvard University Press

Fine, Gary, 1989: The process of tradition: cultural models of change and content. Comparative Social Research 11, 263-277.

Georges, Robert; Owen Jones, Michael, 1995: Folkloristics. An Introduction. Bloomington and Indianapolis: Indiana University Press.

Goffman, Erwin, 1992: Ritual de la interacción. Buenos Aires: Tiempo Contemporáneo.

Greimas, Algirdas; Courtès, Joseph, 1982: Semiótica. Diccionario razonado de la teoría del lenguaje. Madrid: Gredos. 
Ivančič Kutin, Barbara, 2016: Krivopete: Wild Women with Backward-facing Feet in Slovenian Folk Narrative Tradition. Folklore 127/2, 173-195.

Ivančič Kutin, Barbara, 2017. Transformacije (Slovstvene) Folklore v Sodobni Kulturi. Krivopete v Zgornjem Posočju in v Benečiji. Traditiones 46/1-2, 37-54

Kropej, Monika, 2012: Supernatural Beings from Slovenian Myth and Folktales (Studia mythologica Slavica - Supplementa 6). Ljubljana: Založba ZRC, ZRC SAZU

Kropej, Monika; Šmitek, Zmago; Dapit, Roberto, 2010: A Treasury of Slovenian Folklore: 101 Folktales from Slovenia. Radovljica: Didakta.

Labov, William; Waletzky, Joshua, 1967: Narrative analysis: oral versions of personal experience. In: Helm, Jane (ed.), Essays on the Verbal and Visual Arts. Seattle and London: The University of Washington Press, 12-44.

Lotman, Jurij Mijailovich, 1978: Semiótica de la cultura. Madrid: Cátedra.

Mukařovský, Jan, 1977: Detail as the Basic Semantic Unit in Folk Art. In: Burbank, John; Steiner, Peter (eds.), The Word and Verbal Art: Selected Essays. New Haven: Yale University Press, 180-204.

Oring, Elliot, 2012: Just Folklore: Analysis, Interpretation, Critique. Long Beach: Cantilever Press.

Palleiro, Maria, 1990: Estudios de Narrativa Folklórica. Buenos Aires: Filofalsía.

Palleiro, Maria, 2004: Fue una historia real. Itinerarios de un archivo. Buenos Aires: Instituto de Filología y Literaturas Hispánicas de la Universidad de Buenos Aires.

Palleiro, Maria, 2008: Yo creo, vos ¿sabés? Retóricas del creer en los discursos sociales. Buenos Aires: Facultad de Filosofía y Letras de la Universidad de Buenos Aires.

Palleiro, Maria, 2012: Haunted houses and haunting girls: life and death in Contemporary Argentinean folk narrative. In: Bowman, Marian; Valk, Ülo (eds.), Vernacular Religion in Everyday Life: Expressions of Belief. New York \& London: Routledge, 211-229.

Palleiro, Maria, 2016: El cuento folklórico riojano: una aproximación a la narrativa oral. Buenos Aires: La Bicicleta.

Palleiro, Maria, 2018: La dama fantasma. Los laberintos de la memoria en el relato folklórico. Buenos Aires: La Bicicleta.

Palleiro, Maria, 2020: Argentinean and Slovenian folk narratives: classification criteria and comparative approach. In: Palleiro, Maria (ed.), Argentinean and Slovenian Folk Narrative Archives Archivos de Narrativa Folklórica Argentina y Eslovena Buenos Aires: INILFI "Manuel Alvar" Universidad Nacional de San Juan, 71-90.

Palleiro, Maria; Peltzer, Eugenia, in print: Meaning and symbolism of the Salamanca rite in Argentinean popular culture. In: Merriman, Kelly (ed.), The thrill of the Dark: Heritages of Fear, Fascination and Fantasy. Birmingham: Ironbridge Internationa Institute for Cultural Heritage.

Rappaport, Roy, 1992: Ritual. In: Bauman, Richard (ed.), Folklore, Cultural Performance and Popular Entertainments. A Communications-centered Handbook. New York: Oxford University Press, 249-260.

Schechner, Richard, 2004: Performance Theory. London: Taylor and Francis.

Tangherlini, Timothy, 1990: It happened not too far from here. A Survey of Legend Theory and Characterization. Western Folklore 49/4, 371-390.

Thompson, Stith, 1955-1958: Motif-Index of Folk-literature. Copenhagen and Bloomington: Indiana University Press. 
Thompson, Stith, 1993. Motif-Index of Folk Literature. New Enlarged and Revised Edition. Copenhagen and Bloomington: Indiana University Press.

Thoms, William, 1991: La palabra 'Folklore'. Reimpresión de la carta a El Ateneo, 1846. In: Magrassi, Guillermo; Rocca, Manuel (eds.), Introducción al Folklore. Buenos Aires: Centro Editor de América Latina, 37-64.

Valk, Ülo, 2001: The Black Gentleman. Manifestations of the Devil in Estonian Folk Religion. Helsinki: Academia Scientiarum Fennica (Folklore Fellows Communications 276).

Valk, Ülo, 2006: Ghostly Possession and Real Estate: The Dead in Contemporary Estonian Folklore. Journal of Folklore Research 43/ 1, Indiana, 31-51.

Valk, Ülo, 2019: Call for papers to the Guwahati Conference- Online document. https://networks.h-net.org/node/73374/announcements/1984055/conference-belief-narratives-folklore-studies-narrating-

Venturoli, Sofia, 2004: Il paessaggio come testo. La costruzione di un'identità tra territorio e memoria nell' area andina. Bologna: Clueb.

White, Hayden, 1973: Metahistory: The Historical Imagination in Nineteenth-century Europe. Baltimore and London: The Johns Hopkins University Press. 


\section{“IL CAIRÉ” E "IL FANTASMA DI KOMAT": PAESAGGI TESTUALI E PATRIMONIO CULTURALE NEI RACCONTI POPOLARI ARGENTINI E SLOVENI \\ Maria Palleiro \\ $\infty$}

In questo articolo propongo un approccio comparativo a due racconti popolari, uno sloveno ed uno argentino, il cui contenuto semantico esprime identità culturali locali. Entrambi condividono caratteristiche tematiche con ATU 326, "The youth who wanted to learn what fear is" ("Il giovane che voleva imparare cos'è la paura"), e quello argentino aggiunge anche elementi di ATU 330A, "The smith and the Devil" ("Il fabbro e il diavolo"). La versione argentina, registrata in una ricerca sul campo in 1986, é stata riferita dal giovane narratore Cesar Soria, di anni sedici, nella provincia di La Rioja (Palleiro 1990a: 53-54), e la versione slovena é stata registrata da Kropej, Šmitek and Dapit (2015: 100).

L'approccio comparativo é orientato ad individuare similitudini tematici, strutturali e stilistiche simili, insieme a differenze di dettagli. Ogni insieme di caratteristiche tematiche, strutturali e stilistiche comuni viene concepito come una matrice narrativa, che funge da pre-testi da ricreare in contesti narrativi diversi. I dettagli, considerati come unità semantiche di base del discorso narrativo, danno ad ogni matrice nuovi significati, connessi con le identità locali. La trama dei racconti é articolata attorno a queste matrici, e il suo contenuto semantico riflette i conflitti della vita quotidiana di ogni popolo.

I racconti popolari costituiscono un patrimonio culturale immateriale di diversi gruppi locali, come quelli dei contesti sloveni e argentini. Ogni nuova versione conferisce significati contestuali alle matrici narrative, creando paesaggi culturali che diventano in ogni racconto paessagi testuali. Così accade con la versione argentina riguardanti il giovane senza paura, nominato "Il Cairé" - associata anche con il patto con il diavolo- e con quella riguardante "Il fantasma di Komat" e altre anime erranti slovene. La versione slovena riferisce che l'anima di un vicino traditore deve ritornare dall' altro mondo alla terra chiamata "Komat" come un fantasma che porta la pietra di confine sulla sua spalla ogni notte perché ha spostato la pietra miliare per ottenere la terra che apparteneva ad un altro vicino, e quindi riporta un conflitto riguardante alla possesione della terra, proiettato ad un livelo sopranaturale associato con credenze sociali del contesto.

Nel contesto argentino, la matrice narrativa ha anche una manifestazione rituale nella cerimonia della "Salamanca", nella quale si celebra un patto con il diavolo. Questa cerimonia rituale é stata rappresentata dall'artista locale Marino Cordoba in statuette di ceramica, che fanno parte del patrimonio culturale locale, esposte nel Museo Folcloristico di La Rioja. Marino Cordoba ha anche raccontato lo sviluppo sequenziale di questo rito locale, cui racconto verbale viene utilizzato in questo articolo come intertesto per fare un paragone con il testo del giovane narratore Soria. Questa comparazione intertestuale ha mostrato che le convinzioni 
sociali e le credenze della comunità messe in atto nel rito gravitano anche nello spazio del racconto, presentato sia come una leggenda che come un caso reale.

La "Salamanca" serve anche da ispirazione ad eventi performativi come il "festival della Salamanca", che mostra una miscela di culture europee e indigene. Queste espressioni artistiche che mostrano la rilevanza delle credenze sociali e che rivelano la presenza del soprannaturale nella vita quotidiana servono anche come attrazioni turistiche per incentivare la visita ai luoghi storici che conservano tracce delle culture locali.

Sia l'analisi testuale che il percorso intertestuale dei racconti rivelano che le narrazioni orali esprimono rappresentazioni simboliche del soprannaturale nelle diverse culture, e queste rappresentazioni riguardano non solo le esperienze personali ma anche quelle della vita sociale di ogni comunitá, come quelle argentine e slovene. In questo modo, le versioni orali riferite al patto con il diavolo compiuto nel rito della Salamanca fungono da pre-testi sia di statuette iconiche esposte in un museo che di eventi musicali performativi come il festival della Salamanca, che non è solo un'espressione folcliristica ma anche un'attrazione turistica collegata all' invenzione di tradizioni.

Le narrazioni mostrano come il soprannaturale sia rappresentato in contesti come il mondo andino, i cui paesaggi geografici e culturali fanno parte del Quapaq Ñam, il sentiero degli Inca, dichiarato Patrimonio Culturale dell'Umanitá dall' UNESCO. La complessitá dei paesaggi culturali come quegli del mondo andino rende necessario arbitrare meccanismi di tutela per lo sviluppo dei circuiti turistici. Attraverso tali forme di turismo, le persone possono sperimentare gli stili di vita che questi luoghi coinvolgono. I concetti di patrimonio tangibile e immateriale sono strettamente intrecciati, come mostrato nelle narrazioni qui analizzate, che ricreano spazi testuali in cui si respecchiano le identitá locali come quelle slovene e argentine, affermate attraverso le differenze.

Maria Palleiro, Ph.D., Ricercatrice di Ruolo, Universitá di Buenos Aires, Consiglio Nazionale per la Ricerca Scientifica e Tecnologica (CONICET), Argentina, marinespalleiro@gmail.com 